\title{
ORIGENALS (1)
}

\section{$(\mathbf{S N})_{x}$ およびその臭素化物の合成と表面特性 SEM 像と表面積測定}

\author{
宮 崎 栄 三・梅 野 聰 \\ 東京工業大学理学部化学科 $\overline{\mathrm{T}} 152$ 東京都目黑区大岡山 \\ (1982 年 11 月 17 日 受理)
}

\section{Synthesis and Surface Properties of Pure and Brominated (SN) SEM and Surface Area Measurement-}

\author{
Eizo MIYAZAKI and Satoshi UMENO \\ Department of Chemistry, Tokyo Institute of Technology \\ Ookayama, Meguro-ku, Tokyo 152 \\ (Received November 17, 1982)
}

\begin{abstract}
Surface properties of pure and brominated (SN) $x$ crystals were studied by adsorption of Xe and $\mathrm{Kr}$ gases at $78 \mathrm{~K}$ and by scanning electron micrographs. We first report on the surface area of $(\mathrm{SN})_{x}$ and $\left(\mathrm{SNBr}_{y}\right)_{x}$ and its change with heating in vacuo when $y$ is in the range 0.06 to 0.38. The surface area of the $(\mathrm{SN})_{x}$ crystal reaches $72 \mathrm{~m}^{2} / \mathrm{g}$, a value comparable to that of silica gels or other substrates used for metallic catalysts. When $(\mathrm{SN})_{x}$ was brominated, many projecting dewdroplike patterns were observed on the surface and the surface area drastically decreased, i.e., from $72 \mathrm{~m}^{2} / \mathrm{g}$ to $41 \mathrm{~m}^{2} / \mathrm{g}$ at $y=0.06$. When the brominated $(\mathrm{SN})_{x}$ was heated at $70^{\circ} \mathrm{C}$ in vacuo; the projecting patterns disappeared and the surface area slightly recovered.
\end{abstract}

\section{1.はしがき}

$(\mathrm{SN})_{x}$ は金属的性質を屯った鎖状高分子小（Fig. 1)

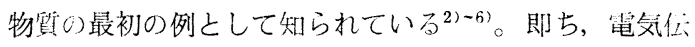
導度は水銀のそ机に半敵し， $4.2 \mathrm{~K}$ では堂盜の 200 倍 になる。また $0.3 \mathrm{~K}$ にて超電学状態になる。一方, 鎖 間の電導性は小さく, $(\mathrm{SN})_{x}$ は極好晎力性の強い物 質とみられる。これらの性質は光反射率扔よび比熱の測 定などによっても確かめられている。しかし，パイエル ス転位を起さない点では，TTF-TCNQ および KCPな どの他の典型的な一次元有機伝導体と異なっている。さ らに, 留導度の摇動効果 ${ }^{7}$, 臨界磁場の異方性 ${ }^{8}$, マイ スナ効果の测定 ${ }^{9)}$ などからの $(\mathrm{SN})_{x}$ 結晶の規則性また は次元性に関する研究も多い。バンド構造やフェルミ面门 の形などに関する最近の理論的計算 ${ }^{27}$ でもの有機伝導 体とは異なる性質をもった物質とみられている。
その他，(SN) xに関しては磁気的，熱的 ${ }^{10)}$, 機械的 蟲度测定 ${ }^{11)}$ な゙も行われている。さらにXPS(2),13) など の電子分光法による研究も報告されている。

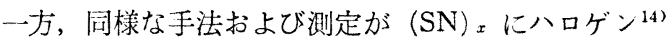
またはアルカリ金属 ${ }^{15)}$, 特に臭素をドープした $\left(\mathrm{SNBr}_{y}\right)_{x}$ (y は SN に対する臭素い分率) についてなされ，多く の報告がある。

しかしながら，これらの研究はいずれも全体としてバ ルクに関する物性的研究である。今日, 多くの金属にお いて表面の物理化学的研究が関心をよび, 多くの成果が 期待されているが，同様な電気伝導性をむつ $(\mathrm{SN})_{x}$ お よびその化合物についての表面化学的またはそれにそっ た研究は存在しない。

表面の規則性の藏い結晶であるグラファイトやハロゲ ン化アルカリなどに低温で $\mathrm{Xe}, \mathrm{Kr}, \mathrm{NO}, \mathrm{H}_{2} \mathrm{O}$ などを 物理吸着させると一定の温度および表面被覆率において 


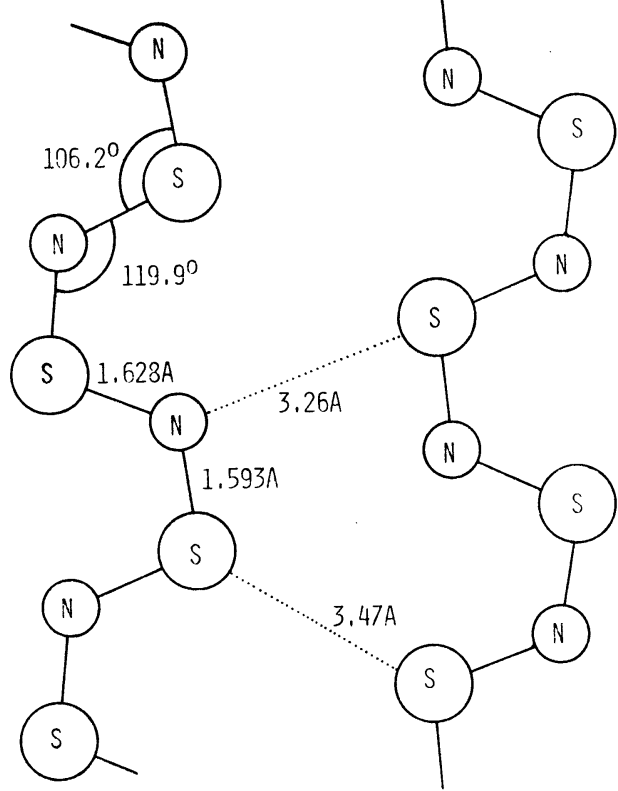

Fig. 1 Crystal structure of $(\mathrm{SN})_{x^{1}}$.

二次元凝縮が生ずることが知ら机ている ${ }^{16}$. 逆に，低温 での物理吸着の実験によって表面の規則性に関する知見 がえられるととが期待される。また，鎖状（綫維状）の 物質の表面積は同一体積について考えると球状のそれよ り $(l / r)^{1 / 3}$ 倍大きい $(l, r$ はそれぞれ䄉維の長さおよび 球の半径）ので充分細い束の（SN） $x$ がえられれば比表 酒積の大きい物質として新しい灾用が期待される。

$(\mathrm{SN}) \times$ の合成は，合成条件の敛しさ，精製の繁雑さ に加えて, 中間体である $\mathrm{S}_{4} \mathrm{~N}_{4}$ 抢よび $(\mathrm{SN})_{x}$ の爆発性 のためか我国では阪大工 (犬石研)および東大物性研（中 由研）の 2 研究公に限ら机ている。合成法自身にもいま だ問題がある。したがって，本研究では，まず合成法に ついて特に注意した点や工夫した点を中心にのべる。つ いで Xe, $\mathrm{Kr}$ ガスの液体窒素温度 $(78 \mathrm{~K})$ におりる吸着 を二次元疑縮に注意して行い，また，BET 法による表 面皘の測定結果についてのべる。さらに，種々の割合で 臭素をドープした化合物 $\left(\mathrm{SNBr}_{y}\right)_{x} \quad(y=0.06 \sim 0.38)$ を合成し, $y$ による表面皘の変化についてのべ, 最後に， その真空排気処理による回復の様子を SEM 像之比較検 執する。

\section{2. $(\mathrm{SN})_{x}$ および $\left(\mathrm{SNBr}_{y}\right)_{x}$ の合成}

$(\mathrm{SN})_{x}$ は以下の化学式により表わされるように $\mathrm{S}_{4} \mathrm{~N}_{4}$, $\mathrm{S}_{2} \mathrm{~N}_{2}$ の中間生成物を経るプロセスにより合成した。
$6 \mathrm{SCl}_{2}+16 \mathrm{NH}_{3} \rightarrow \mathrm{S}_{4} \mathrm{~N}_{4}+2 \mathrm{~S}+12 \mathrm{NH}_{4} \mathrm{Cl}$ または

$6 \mathrm{~S}_{2} \mathrm{Cl}_{2}+16 \mathrm{NH}_{3} \rightarrow \mathrm{S}_{4} \mathrm{~N}_{4}+8 \mathrm{~S}+12 \mathrm{NH}_{4} \mathrm{Cl}$

$\mathrm{S}_{4} \mathrm{~N}_{4} \rightarrow \mathrm{S}_{2} \mathrm{~N}_{2} \rightarrow(\mathrm{SN})_{x}$

$\mathrm{S}_{4} \mathrm{~N}_{4}$ は市販されていないため, こてでは Jolly ら， Arnold ら，金藤ら，中田らの方法を参考にして合成し た2),37,5),17)。市販の $\mathrm{S}_{2} \mathrm{Cl}_{2}$ または $\mathrm{SCl}_{2}$ を減压蒸溜して 精製し，乙机を $\mathrm{N}_{2}$ 気流中で $\mathrm{CCl}_{4}$ 亿溶かす。ついで $\mathrm{Cl}_{2}$ 気体を飽和した後充分かく伴しながら $\mathrm{NH}_{3}$ ガスを導入 した。精製した $\mathrm{NH}_{3}$ ガスを吹込むにつれて，黒褐色 $\rightarrow$

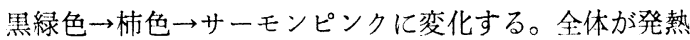
反応で温度が上昇しない上うに適宜冷却しながら行うが 爆発を恐れて冷却しすぎると $\mathrm{S}_{4} \mathrm{~N}_{4}$ の収量が落ち $\mathrm{S}$ を多 く含んだ $\mathrm{S}_{7} \mathrm{NH}$ 等が多く生成した。この温度調整が $\mathrm{S}_{4} \mathrm{~N}_{4}$ 合成成功のための一つのポイントであった。生成 した $\mathrm{NH}_{4} \mathrm{Cl}$ を含む物質を照濁させると $\mathrm{NH}_{4} \mathrm{Cl}$ は水に: 溶けて粗製 $\mathrm{S}_{4} \mathrm{~N}_{4}$ が残る。こ机在やセトトリル，エー テルで洗浄後乾燥した。

黄褐色ないし茶褐色をした粗製 $\mathrm{S}_{4} \mathrm{~N}_{4}$ は $\mathrm{S}_{8}, \mathrm{~S}_{7} \mathrm{NH}$ 等 の不純物が其存するので，乙㞦らを除くため，さらに数 回エーテルで振洫して上澄液（黄褐色）を除いた。つい でソックスレー抽出器でジオキサンを用いて $\mathrm{S}_{4} \mathrm{~N}_{4}$ を抽 出した。抽出液をロータリーエバポレーターによってジ オキサンを除いて浱縮し，エーテルで乾燥した。乾燥 $\mathrm{S}_{4} \mathrm{~N}_{4}$ を熱ベンゼンで再結鼠をくり返した。最後に, $80^{\circ} \mathrm{C}$ の真空下で加熱昇華させて, $\mathrm{S}$ 㧍よび炭化水素を 除去して精製 $\mathrm{S}_{4} \mathrm{~N}_{4}$ をえた。

$\mathrm{S}_{4} \mathrm{~N}_{4}$ から $(\mathrm{SN})_{x}$ への合成は McDiarmid 弓 ${ }^{18)}$ 抢上 び金藤ら ${ }^{177,199}$ の方法を参考にして行った。即ち，精製 $\mathrm{S}_{4} \mathrm{~N}_{4}$ を高真空容器内で加熱 $\left(80^{\circ} \mathrm{C}\right)$ 昇華させ，乙れを 熱した銀ウール $\left(220^{\circ} \mathrm{C}\right)$ に通して $(\mathrm{SN}) \times$ の単量体であ る $\mathrm{S}_{2} \mathrm{~N}_{2}$ を冷却トラップ $(78 \mathrm{~K})$ 上に凝縮させる。次に， $-10^{\circ} \mathrm{C}$ に保ちながら真空排氛を充分行って黒褐色の物 質を除くと青灰色の精製 $\mathrm{S}_{2} \mathrm{~N}_{2}$ がえられた。 $\mathrm{S}_{2} \mathrm{~N}_{2}$ は本 来無色であるが $-10^{\circ} \mathrm{C}$ でも実際には重合が徐々に進む ために青灰色を呈している。生成した $\mathrm{S}_{2} \mathrm{~N}_{2}$ を空温に戻 し，冷却した試料採取管 $\left(-10^{\circ} \mathrm{C}\right)$ に移して $(\mathrm{SN}) \times に$ 合成させた。一週間 $-10^{\circ} \mathrm{C}$ 亿保った後, 試料管を室温 に戻し, 約 3 日間排父して未重合 $\mathrm{S}_{2} \mathrm{~N}_{2}$ を除去した。さ らに $75^{\circ} \mathrm{C}$ に加熱しながら数時間排気し最終的に精製 $(\mathrm{SN})_{x}$ をえ，測定試料とした。

$(\mathrm{SN})_{x}$ の臭素化物は $(\mathrm{SN})_{x} に \mathrm{Br}_{2}$ 蒸気を数十Torr 0圧で処定㫪導入して合成した。

なお，(SN) $x$ は同一 $\mathrm{S}_{4} \mathrm{~N}_{4}$ から同様な方法および条 件下で 2 回作られた。最初に合成した試料を試料 1 ，そ の後に作られた試料を試料 2 とする。後にのべるように 
試料 1 と 2 では色, 組成等は変らないが, 表面積が大き く異なるととがわかった。

\section{3. $(\mathrm{SN})_{x}$ および $\left(\mathrm{SNBr}_{y}\right)_{x}$ の固定と走査 電子顕微鏡 (SEM) 像}

合成した $(\mathrm{SN}) x$ は空気中で安定で, 元素分析, $\mathrm{X}$ 線 回折により組成および構造を確認した。Table 1 亿元 素分析の結果を示す。比較のため他の研究者の結果を合 せて示す。結果は理論值と測定誤差範囲内で一致し, ま た，試料 1 と 2 の分析值も一致する。X線回折の結果も 他の研究者のあのとほとんど一致するととがわかった。

$(\mathrm{SN})_{x}$ をまず金属顕微鏡で観察すると美しい金色の 光沢をむつ 1 2 $\mathrm{mm}$ 角の結晶である。次に, Fig. 2 に 試料 1 の SEM 像を示す。 S-N 鎖方向に配向して結晶 が形成されていることがわかる。また, S-N 鎖は直径 が数十 $\mathrm{nm}$ の絨維（フィブリル）が束となって太さ数百 $\mathrm{nm}$ から数 $\mu \mathrm{m}$ の紻維束 (バンドル) を構成していると とがわかる。Fig. 2-C はその末端を示す。

一方，この $(\mathrm{SN}) \times$ 亿臭素をドープすると色は茶褐色 に変色する。さらに著しい変化は表面に露滴状の突起が 一面に見出さ机るととである。との様子を Fig. 3 亿試 料 2 の場合によって示す。写真は同一場所の SEM 像で あるが突起の大きさや位置はランダムである。( $\left.\mathrm{a}^{\prime}\right)$, $\left(b^{\prime}\right),\left(c^{\prime}\right),\left(d^{\prime}\right)$ はそれぞれ (a), (b), (c), (d) の中 央部分を 6.3 倍（総合倍率で 6300 倍）に拡大したあの である。(a)，(a') は臭素をドープしないときの $(\mathrm{SN})_{x}$ で，乙机にわずか $\mathrm{SN}$ に対して 0.06 当量の $\mathrm{Br}$ をドー プすると（b)，( $\left.\mathrm{b}^{\prime}\right)$ のように変化する。さらに $\mathrm{Br}$ を 添加すると (c), ( $\left.\mathrm{c}^{\prime}\right)$ のごとく表面は著しく変化する。 これを加熱真空排気すると, 突起はほ上んど失われてい る(後述)。乙のような表面変化が SEM 像により明ら かにされたのは本報告が初めてである。

Table 1 Results of Elemental Analyses of $(\mathrm{SN})_{x}$

\begin{tabular}{lrccccl}
\hline Workers & Ref. & $\mathrm{N}$ & $\mathrm{S}$ & $\mathrm{O}$ & $\mathrm{C}$ & $\mathrm{H}$ \\
\hline Temple I* & 27 & 30.11 & 69.60 & & & \\
Temple II** & 27 & 28.96 & 66.10 & 4.93 & 0.13 & 0.42 \\
IBM & 28 & 29.60 & 69.61 & - & 0 & 0.2 \\
Penn & 18 & 30.56 & 69.51 & - & 0 & 0 \\
This work I' & & 31.08 & 68.70 & - & 0 & 0 \\
This work II" & & 30.91 & 69.09 & - & 0 & 0 \\
Calcd. & & 30.40 & 69.60 & & & \\
\hline
\end{tabular}

* Unexposed crystal, ** Exposed crystal to air.

' Sample No. 1, "Sample No. 2.
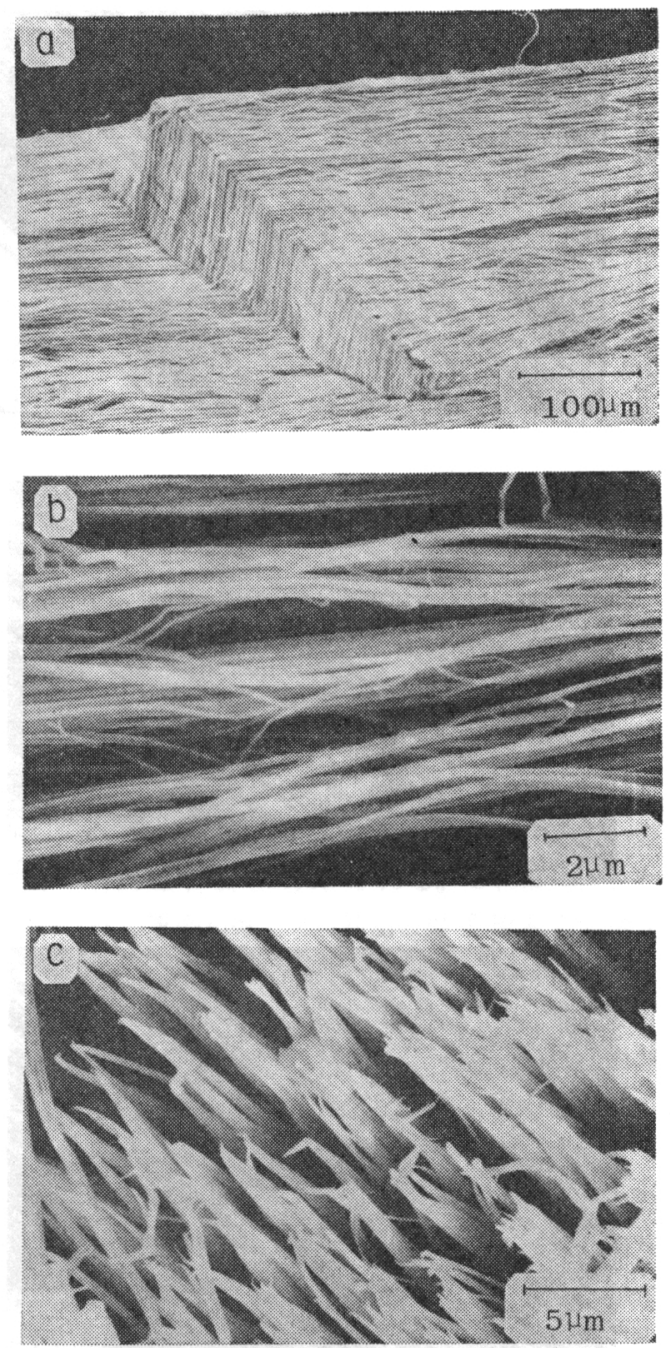

Fig. 2 Scanning electron micrographs (SEM) of $(\mathrm{SN})_{x}$ (sample No. 1).

\section{4. $\mathrm{Xe}, \mathrm{Kr}$ の吸着等温線亡表面の性質}

$(\mathrm{SN})_{x}$ 表面上での気体分子の一次元的および二次元 的凝縮現象の有無をしらべ, また, 表面積を知るため に, $78 \mathrm{~K}$ における Xe, $\mathrm{Kr}$ の吸着測定を行った。Xe の $78 \mathrm{~K}$ における飽和蒸気圧は 0.00217 Torr で電離真 空計を用いると数 $\mathrm{cm}^{2}$ の表面積を測定するととができ $3^{20)}$ 。 Kr を用いると $78 \mathrm{~K}$ での飽和蒸気圧は 8 Torr で適当な压力計を用い机ば数百 $\mathrm{cm}^{2}$ 以上の表面積を容 易に測定するととができる ${ }^{21 !}$ 。前者では吸着系部分を充 分焼き出して $10^{-8}$ Torr 以下の真空に保持できること が必要である。 Kr では, 著者らが開発した高周波イン ダクタンス型圧力計 ${ }^{22)}$ 用いた。

Fig. 4 亿試料 1 亿対する Xe の吸着等温線を示す。 

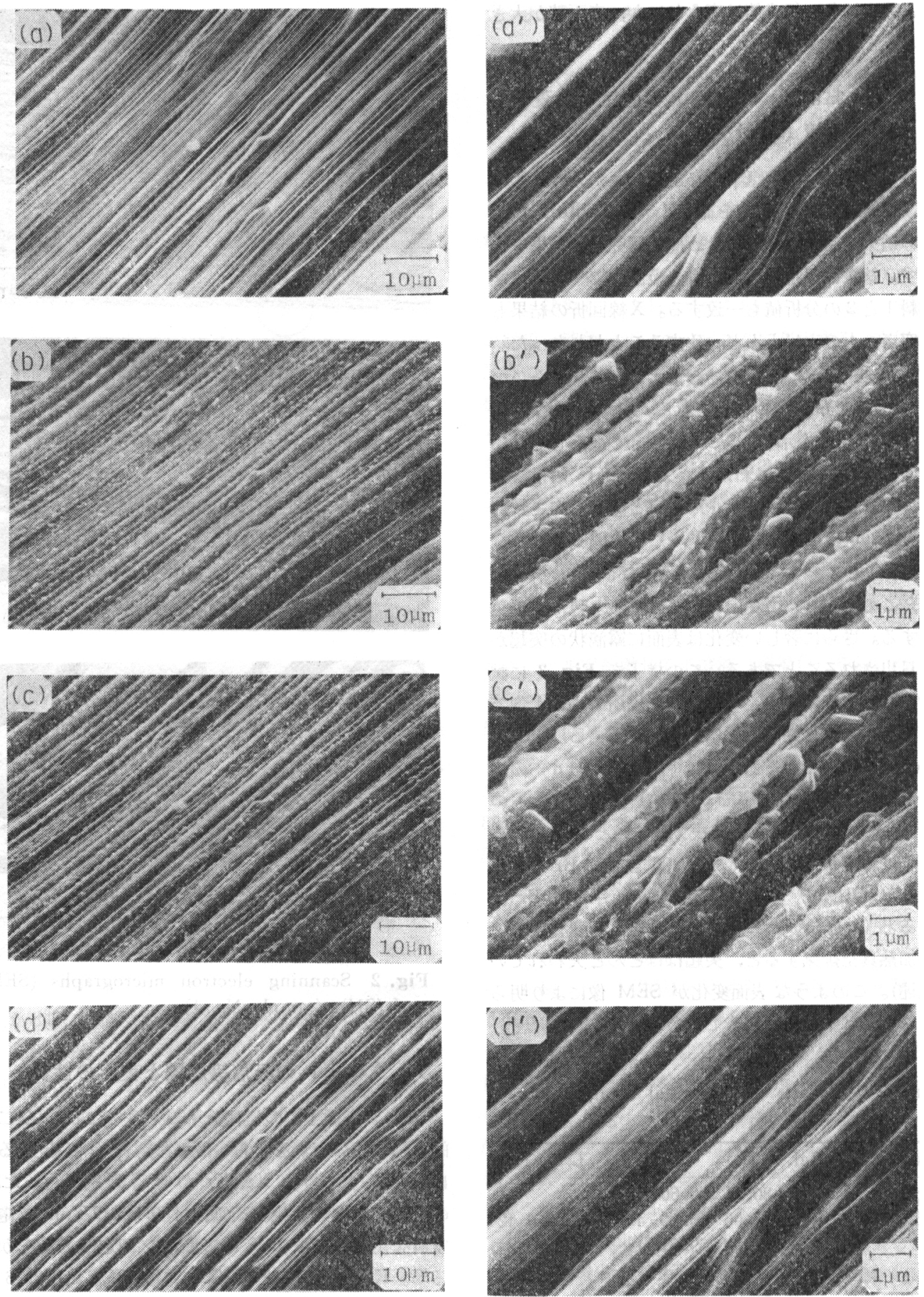

Fig. 3 SEM of brominated $(\mathrm{SN})_{x},\left(\mathrm{SNBr}_{y}\right)_{x}$ (sample No. 2).

(a) and $\left(\mathrm{a}^{\prime}\right)$; $(\mathrm{SN})_{x}$ before exposure to bromime.

(b) and $\left(\mathrm{b}^{\prime}\right)$; (SNBro.06) $x$.

(c) and $\left(\mathrm{c}^{\prime}\right) ;\left(\mathrm{SNBr}_{0.38}\right)_{x}$.

(d) and $\left(\mathrm{d}^{\prime}\right)$; after the (SNBro.38) $)_{x}$ was evacuated at $70^{\circ} \mathrm{C}$ for $20 \mathrm{~h}$.

Magnification: (a), (b), (c) and (d); $\times 1000$

$\left(a^{\prime}\right),\left(b^{\prime}\right),\left(c^{\prime}\right)$ and $\left(d^{\prime}\right) ; \times 6300$ 


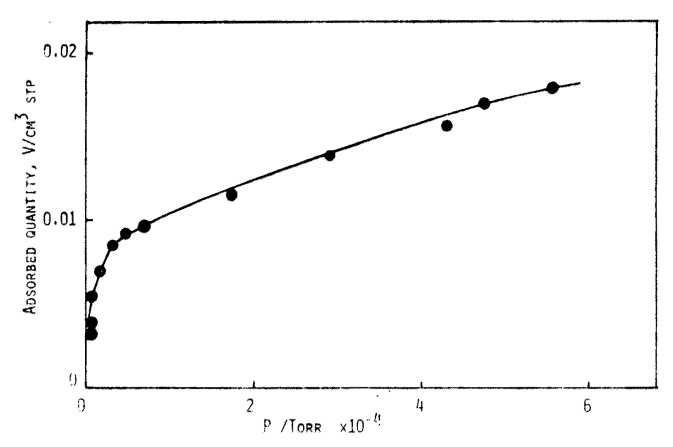

Fig. 4 Adsorption isotherm of $\mathrm{Xe}$ on $(\mathrm{SN})_{x}$ at $78 \mathrm{~K}$ (sample No. 1).

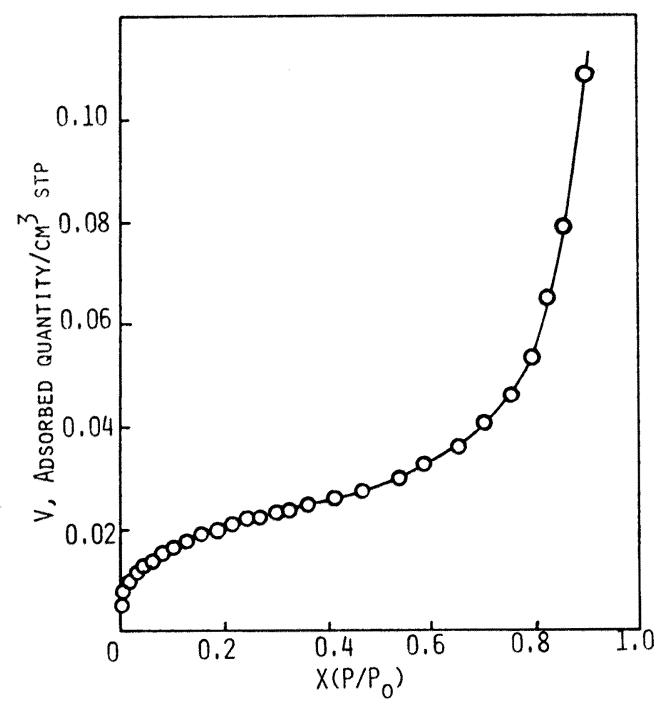

Fig. 5 Adsorption isotherm of $\mathrm{Kr}$ on $(\mathrm{SN})_{x}$ at $78 \mathrm{~K}$ (sample No. 1). $\mathrm{P}_{n}$; saturated vapor pressure of of $\mathrm{Kr}$.

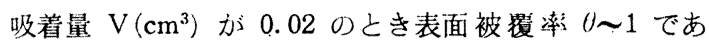
る。Fig. 4 から明らかなように，(SN)×では $\theta$ がはぶ 1 まで滑らかな曲線である。Fig. 5 に Kr による吸着 等温線を示すが, 典型的な $\mathrm{S}$ 字型曲線で Xe と同様曲線 は滑らかである。 $\mathrm{BN}, \mathrm{CaI}_{2}$ 型層状結晶および $\mathrm{KCl}$, $\mathrm{MgO}$ などの均一度の高い表面では下地結晶構造に適合 した規則的構造の吸着厤を作る傾向が強く, 吸着質とし て Xe, Kr などを低温で吸着させると二次元凝縮の現 象を示すことが知られている16)。乙れらの規則性の高い 表面では,したがって, 三次元的多分子層吸着を仮定した BET 理論式への適用性はよくない。Fig. 6 に Xe, Kr についての BET プロットを示す。襾気体共よい直線性 を示し，BET 式によく適合することがわかる。

以上のように, $(\mathrm{SN}) \times$ の收着等温線には二次元凝縮



Fig. 6 BET plots of $\mathrm{Xe}(\bullet)$ and $\mathrm{Kr}(0)$ on $(\mathrm{SN})_{x}$

にもとづく不連続階段状等温線が見出されなかったこ と，および BET 式が適用できる点などから $(\mathrm{SN})_{x}$ は 少くと屯ミクロには結晶性のあまり良くない不均一表面 をむつ配向性物質と考えられる。これは $\mathrm{S}_{2} \mathrm{~N}_{2}$ から $(\mathrm{SN})_{x}$ への重合がモノマー結晶の格子規制を直接受け るトポケミカル重合であるととと関係しているとみられ る。即ち, このトポケミカルの重合に際して出発物質と 生成物質の結晶構造の違いが原因になって重合が内部に 進行するに従って全体に否が生じる ${ }^{23)}$ 。乙れが結晶の規 則性を低下させている一つの原因であろう。

次に, $(\mathrm{SN}) \times$ の構造からみて吸着分子が一次元的に 配列する場合も考えられる。最隣接分子間だけの相互作 用では一次元凝縮による相転移は現われないととが知ら れている ${ }^{24)}$ 。乙れは何らかの形, 例えば飽和蒸気の変化 などで吸着等温線に反映するとみられるが，本実験でえ られた吸着等温線にはそれに対応する現象は観察されな かった。

試料 2 に対してあ二次元凝縮は見出されなかった。 以上のととから, $(\mathrm{SN})_{x}$ は鎖状の, 電気伝導度その 他の物性からみると一次元性が強いが, 物理吸着による 表面特性からみると一次元的性質の認められない三次元 的性質をもった物質と結論できよう。

\section{5. (SN $)_{x}$ の表面積と奥素添加による変化}

Fig. 6 に示す BET プロットの直線の勾配と切片か ら BET 表面積を求めることができる。Xe の吸着断面 皘を $25 \mathrm{~A}^{225)}$ ，Kr のそれを $18.5 \mathrm{~A}^{226)}$ として計算する と試料 1 では，それぞれ， $0.949 \mathrm{~m}^{2} / \mathrm{g}$ および $0.945 \mathrm{~m}^{2} / \mathrm{g}$ と $\mathrm{Xe}$ と $\mathrm{Kr}$ では極めてよい一致を示した。

試料 2 についても同様な吸着実験を試みたところ, 表 


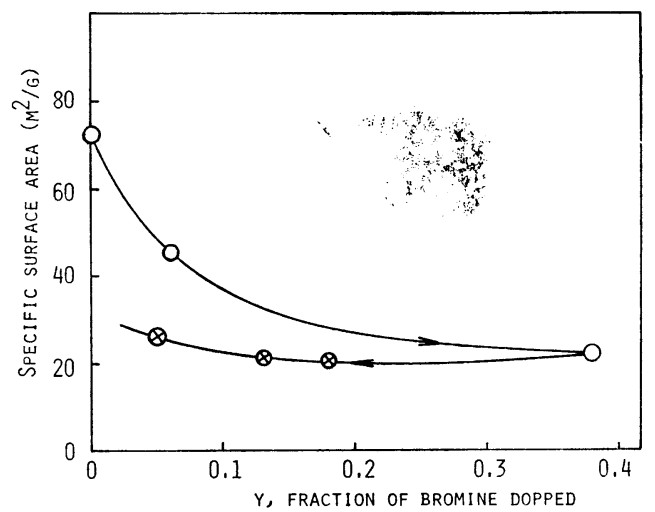

Fig. 7 Variation of specific surface area of the $(\mathrm{SN})_{x}$ with the fraction of doped bromine (y). $\otimes$; surface area after evacuated at $70^{\circ} \mathrm{C}$ $\rightarrow$ shows the experimental sequence.

面積が $72 \mathrm{~m}^{2} / \mathrm{g}$ と武料 1 亿比し 76 倍の表面皘をあつと とがわかった。との值は触媒の坦体に用いられる物質の 表面積に匹敵する大きさである。試料 1 の SEM 像か 弓, 䄉維束の平均直径を $1 \mu \mathrm{m}$ と仮定して計算すると表 面皘は $1 \mathrm{~m}^{2} / \mathrm{g}$ となり BET 表面積とほぐ一致する。 てれを考虑すると, 試料 2 の瀻維束は試料 1 のそれより 細く平均直径が 10 20 nm であるととが推定される。 SEM 像からは平均的な值は決めにくいが，試料 1 亿比 較してより微細な緎維束を構成しているようにみえる。 てのように，同一 $\mathrm{S}_{4} \mathrm{~N}_{4}$ から同様な方法で作った $(\mathrm{SN})_{x}$ の表面積が大きく異なる原因，およびバンドルの束の大 きさ決める実験条件については現在のとてろ明らかでな い。乙の条件が明らかになればさらに表面積の大きな $(\mathrm{SN})_{x}$ を作るととあ困難でないと思われる。

次に，Fig. 7 に $(\mathrm{SN}) \times$ に臭素を加えたときの表面 積の変化を試料 2 亿ついて示す。SN に対し $10 \%$ 以下 の $\mathrm{Br}$ の添加で表面積は $1 / 2$ 以下に急減するととがわ かる。それ以上の添加によっては表面積はあまり変化し ない。一方，すでに述べたように，臭素添加によって表 面に突起が生ずるが (Fig. $\left.3(\mathrm{~b}),\left(\mathrm{b}^{\prime}\right),(\mathrm{c}),\left(\mathrm{c}^{\prime}\right)\right)$ 乙 れは $y=0.06(\mathrm{~b})$ および $\left.\left(\mathrm{b}^{\prime}\right)\right)$ ですでに顕著に観察 される。色む金色から青紫色偣化する。SEM 像では 乙の露滴状突起部分によって表面積が増加すると予想さ れるが実際には大きく減少している。さらに，一度臭素 化した試料を $70^{\circ} \mathrm{C}$ で加熱しながら真空排気すると表面 積がわずかながら回復するととが認められた（Fig. 7 の 一®- 線)。しかし，完全には元に杘らない。その場合， 加熱排気によって表面の突起はほぶ消失する〔Fig. 3 $(\mathrm{d}),\left(\mathrm{d}^{\prime}\right)$ 了之同時に, 試料の色は銅色に変色している。 これらの SEM 像からは, 臭素化は均一に行われる
わけではなく $y$ 值はあくまで平均的な值であるとみら れる。また，フィブリル内に入った臭素化物は局在した 状態で成長し，それが表面につき出るか，または，より 表面に近い部分を持ち上げて突起を作っていると考えら れるが，詳しいととは今後の問題として残される。

なお，本研究の一部は文部省科学研究費補助金により 行われたととを付記する。

\section{文 献}

1) M. J. Cohen, A. F. Garito, A. J. Heeger, A. G. Macdiamid, C. M. Mikuluski and M.S. Saran : J. Am. Chem. Soc. 98 (1977) 3844.

2）金藤敬一, 谷村勝己, 吉野勝美, 犬石嘉雄: 応用 物理 46 (1977) 299 .

3) 中田一郎：応用物理 49 (1980) 594.

4) 三谷洋興，国府田隆夫：固体物理 15 (1980) 625.

5) 中田一郎, 小田祺景, 永野 弘：固体物理 16 (1981) 408.

6) 吉野勝美, 山辺時雄: 化学と工業 32 (1979) 237.

7) R.L. Civiak, C. Elbaum, L.F. Nichols, H.I. Kao and M. M. Labes: Phys. Rev. B14 (1976) 5413.

8) L. J. Azevedo, W. G. Clark, G. Deutscher, R. L. Greene, G.B. Street and L. J. Suter: Solid State Commun. 19 (1976) 197.

9) Y. Oda, H. Takenaka, H. Nagano and 1 . Nakada : Solid State Commun. 32 (1979) 659.

10) D. C. Weber and C. T. Ewing: Inorg. Chem. 16 (1977) 3025.

11) N. Brown and C. K. Chiang: J. Materials Sci. 14 (1979) 49.

12) L. Ley: Phys. Rev. Lett. 35 (1975) 1796.

13) P. Mengel, P. M. Grant, W. E. Rudge, B. H. Schechtman and D. W. Rice : Rhys. Rev. Lett. 35 (1975) 1803.

14) W. D. Gill, W. Bludau, R. H. Geiss, P.M. Grant, R. L. Greene, J. J. Mayerle and G. B. Street: Phys. Rev. Lett. 38 (1977) 1305.

G. B. Street, W. D. Gill, R. H. Geiss, R. L. Greene and J. J. Mayerle: Chem. Commun. (1977) 407.

15) K. Kaneto, S. Sasa, K. Yoshino and Y. Inui : Solid State Commun. 40 (1981) 889.

16) D. M. Young and A.D. Crowell : Physical Adsorption of Gases (1962), Butterworths, London（ガスの物理吸着, 高石, 古山訳, 珄業 圀書, 1966)

P. Robert and Y. Iarher: Phys. Rev. Lett. 40 (1978) 1275; J. Suzanne, J.P. Coulomb, M. Bienfait, M. Matecki, A. Thomy, B. Croset and C. Marti : ibid 41 (1978) 760 ; M. Matecki, A. Thomy and X. Duval: Surface Sci. 120 (1982) 223.

17）金藤敬一：学位論文（阪大工，1976） 
18) C. M. Mikulski, P. J. Russo, M. S. Saran, A. G. MacDiarmid, A.F. Garito and A.J. Heeger : J. Am. Chem. Soc. 97 (1975) 6358.

19) 金滕敬一：私言

20) P. Chenebault and A. Schurenkamper: J. Phys. Chem. 69 (1965) 2300.

21) A. J. Kosenberg: J. Am. Chem. Soc. 78 (1956) 2929.

22) I. Yasumori, S. Ohno and E. Miyazaki: Bull. Chem. Soc. Jpn. 40 (1967) 769.
23) R. H. Baughman and R. R. Chance: J. Polym. Sci. 14 (1976) 2019.

24) R. B. McQuistan and S. J. Lichtman : J. Vac. Sci. Technol. 10 (1973) 890.

25) W. A. Cannon: Nature 197 (1963) 1000.

26）触媒学会編，触媒実験マニュアル（植書店，1971）

27) M. M. Labes, P. Love and L. G. Nichols : Chem. Rev. 79 (1979) 1.

28) R. L. Greene, P. M. Grand and G. B. Street : Phys. Rev. Lett. 34 (1975) 89. 